University of New Hampshire

University of New Hampshire Scholars' Repository

$4-15-2011$

\title{
High-frequency measurements of methane ebullition over a growing season at a temperate peatland site
}

Jordan P. Goodrich

University of New Hampshire - Main Campus

Ruth Varner

University of New Hampshire - Main Campus, ruth.varner@unh.edu

Steve Frolking

University of New Hampshire - Main Campus, steve.frolking@unh.edu

Bryan N. Duncan

NASA

P Crill

Stockholm University

Follow this and additional works at: https://scholars.unh.edu/earthsci_facpub

\section{Recommended Citation}

Goodrich, J. P., R. K. Varner, S. Frolking, B. N. Duncan, and P. M. Crill (2011), High-frequency measurements of methane ebullition over a growing season at a temperate peatland site, Geophys. Res. Lett., 38, L07404, doi:10.1029/2011GL046915.

This Article is brought to you for free and open access by the Earth Sciences at University of New Hampshire Scholars' Repository. It has been accepted for inclusion in Earth Sciences Scholarship by an authorized administrator of University of New Hampshire Scholars' Repository. For more information, please contact Scholarly.Communication@unh.edu. 


\title{
High-frequency measurements of methane ebullition over a growing season at a temperate peatland site
}

\author{
Jordan P. Goodrich, ${ }^{1}$ Ruth K. Varner, ${ }^{1}$ Steve Frolking, ${ }^{1}$ Bryan N. Duncan, ${ }^{2}$ \\ and Patrick M. Crill ${ }^{3}$ \\ Received 28 January 2011; revised 11 March 2011; accepted 15 March 2011; published 15 April 2011.
}

[1] Bubbles can contribute a significant fraction of methane emissions from wetlands; however the range of reported fractions is very large and accurate characterization of this pathway has proven difficult. Here we show that continuous automated flux chambers combined with an integrated cavity output spectroscopy (ICOS) instrument allow us to quantify both $\mathrm{CH}_{4}$ ebullition rate and magnitude. For a temperate poor fen in 2009, ebullition rate varied on hourly to seasonal time scales. A diel pattern in ebullition was identified with peak release occurring between 20:00 and 06:00 local time, though steady fluxes (i.e., those with a linear increase in chamber headspace $\mathrm{CH}_{4}$ concentration) did not exhibit diel variability. Seasonal mean ebullition rates peaked at $843.5 \pm 384.2$ events $\mathrm{m}^{-2} \mathrm{~d}^{-1}$ during the summer, with a mean magnitude of $0.19 \mathrm{mg} \mathrm{CH}_{4}$ released in each event. Citation: Goodrich, J. P., R. K. Varner, S. Frolking, B. N. Duncan, and P. M. Crill (2011), High-frequency measurements of methane ebullition over a growing season at a temperate peatland site, Geophys. Res. Lett., 38, L07404, doi:10.1029/2011GL046915.

\section{Introduction}

[2] Natural wetlands are the largest source in the global atmospheric $\mathrm{CH}_{4}$ budget, with highly variable estimates ranging from 100-231 Tg $\mathrm{CH}_{4} \mathrm{yr}^{-1}$ [Houweling et al., 2000; Wuebbles and Hayhoe, 2002]. Emissions are the net result of $\mathrm{CH}_{4}$ production in the anaerobic zone minus the oxidation of some fraction of the $\mathrm{CH}_{4}$ as it moves from the wetland soil to the atmosphere; $\mathrm{CH}_{4}$ transport occurs by diffusion through the soil matrix, diffusion through plant aerenchyma that bypasses the soil matrix, and subsurface $\mathrm{CH}_{4}$ bubble movement and release or ebullition [Whalen, 2005]. Since changes in soil moisture and temperature affect the emission of $\mathrm{CH}_{4}$ from temperate and northern peatland areas, these ecosystems are hypothesized to produce a significant positive feedback with climate change [Arneth et al., 2010]. The climate response of these ecosystems is complicated by the interactions between thermal, hydrological and plantecological processes [Crill et al., 1988; King et al., 1998; Bubier et al., 2005], which all have the potential to alter $\mathrm{CH}_{4}$ production, oxidation and transport dynamics [Segers, 1998; Bartlett et al., 1990; Strack et al., 2005].

\footnotetext{
${ }^{1}$ Complex Systems Research Center, University of New Hampshire, Durham, New Hampshire, USA.

${ }^{2}$ NASA Goddard Space Flight Center, Greenbelt, Maryland, USA.

${ }^{3}$ Department of Geological Sciences, Stockholm University, Stockholm, Sweden.
}

Copyright 2011 by the American Geophysical Union. 0094-8276/11/2011GL046915
[3] Much uncertainty in estimates of peatland $\mathrm{CH}_{4}$ emissions stems from the difficulty in adequately sampling the high spatial and temporal variability of fluxes. In particular, ebullition has been difficult to quantify due to the highly stochastic nature of this flux pathway. Several methods have been employed to estimate and characterize the magnitude of ebullitive release as well as the frequency with which it occurs [Coulthard et al., 2009], and reported rates range from 0-35,000 $\mathrm{mg} \mathrm{CH}_{4} \mathrm{~m}^{-2}$ day $^{-1}$, though typical values are on the order of $\sim 1000 \mathrm{mg} \mathrm{CH} \mathrm{m}^{-2}$ day $^{-1}$ [Bartlett and Harriss, 1993; Comas and Slater, 2007; Tokida et al., 2007]. Due to the variety of approaches taken to quantify ebullition fluxes, it is unclear to what degree the reported range is the result of site-to-site variation as opposed to differences in methodology and interpretation. For instance, subsurface gas trap funnels cannot fully characterize individual bubble events [Strack et al., 2005], while static chamber methods are limited to sampling at low temporal resolution within a chamber closure and by the duration of field campaigns [Tokida et al., 2007]. Furthermore, certain methods require assumptions of basic characteristics such as $\mathrm{CH}_{4}$ concentration within bubbles [Glaser et al., 2004].

[4] As a first step towards reducing methane flux uncertainty, we have developed a new method for quantifying both ebullition magnitude and timing using high temporalresolution $\mathrm{CH}_{4}$ concentration data $(0.5 \mathrm{~Hz})$ within continual (every $0.2-0.25 \mathrm{hr}$ ) chamber closures. Here we present an analysis of 8 months of $\mathrm{CH}_{4}$ ebullition measurements, determining event timing and magnitude with an off-axis integrated cavity output spectroscopy (ICOS) laser (LGR Inc. Mountain View, CA, USA model DLT-100) operating in an automated chamber system at a temperate poor fen in New Hampshire, USA.

\section{Methods}

[5] Ten automated chambers $(45.7 \times 45.7 \mathrm{~cm}$ at the base and either 68 or $34 \mathrm{~cm}$ tall depending on vegetation) were installed at Sallie's Fen $\left(43^{\circ} 12.5^{\prime} \mathrm{N}, 71^{\circ} 03.5^{\prime} \mathrm{W}\right)$ in the spring of 2000 [Burrows et al., 2005]. Vegetation cover varied among chambers to accommodate the dominant species of the fen, which included Carex rostrata, Chamaedaphne, Vaccinium oxycoccus and a generally continuous cover of Sphagnum spp. [Bubier et al., 2003].

[6] In 2009, an ICOS laser was incorporated into the automated chamber system. From April 27 to September 14, 2009 , chambers were cycled through an 18-minute program (closed from minute 6 to minute 12) giving 80 closures per day. From September 15 to December 19, 2009 the cycle was modified to 12 minutes (closed from minute 5 to 

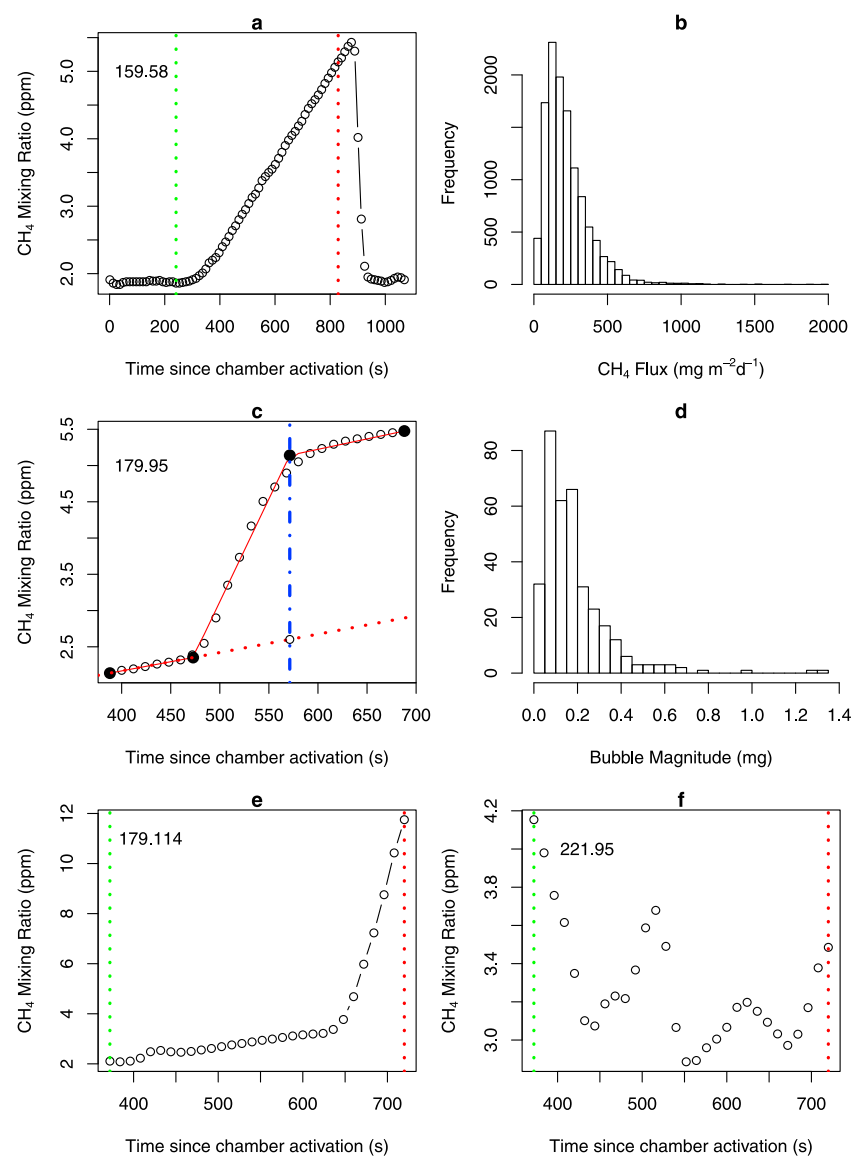

Figure 1. Examples of chamber closure $\mathrm{CH}_{4}$ mixing ratio time series for (a) steady flux in which the headspace $\mathrm{CH}_{4}$ concentration is linear with time; this may represent diffusion through peat, water, plants and/or steady ebullition of micro bubbles; (c) ebullition episode fit with piece-wise linear function to quantify magnitude; solid red lines denote best linear fits for each segment while the dotted red line indicates the trajectory of the initial $\mathrm{CH}_{4}$ concentration increase were no bubble to have occurred and the dashed blue line indicates when the bubble has finished mixing within the chamber and linear buildup resumes, (e) ebullition episode that cannot be fit with piece-wise linear function, and (f) flux that did not meet $0.8-\mathrm{R}^{2}$ criteria for steady flux analysis or the short-duration rapid increase in concentration criteria for ebullition. (b) Flux magnitude frequency distribution for 14,582 steady fluxes and (d) bubble magnitude distribution for 624 quantifiable ebullition events during 27 April19 Dec. 2009. There were 2,093 measurements with identifiable but not quantifiable ebullition episodes, and 2,770 rejected measurements. Numbers in Figures 1a, 1c, 1e, and if refer to time of chamber activation, in fractional day of year. Vertical green and red lines in Figures 1a, 1e, and 1f denote when the chamber closed and opened, respectively.

minute 11 during the day and minute 1 to minute 11 during the night $-20: 00$ to $06: 00$ ), giving 120 closures per day. Chamber headspace $\mathrm{CH}_{4}$ concentration was measured at $0.5 \mathrm{~Hz}$, and averaged to 12 -second mean values in order to match the frequency of environmental data collected by the datalogger. Standard chamber flux calculations [Bubier et al., 2002] were made for any chamber closure resulting in linear increase of headspace $\mathrm{CH}_{4}$ over time (Figure 1a). Chamber closures resulting in nonlinear $\mathrm{CH}_{4}$ concentration time series were separated into episodic ebullition events or poor quality data (Figures 1c, 1e, and 1f). Ebullition was characterized by a sudden increase in the slope of the $\mathrm{CH}_{4}$ mixing ratio over time for short durations; generally greater than $8 \mathrm{nmol} \mathrm{mol}^{-1} \mathrm{~s}^{-1}$ for less than $120 \mathrm{~s}$ (Figures $1 \mathrm{c}$ and $1 \mathrm{e}$ ), while irregular mixing ratio data were rejected (Figure 1f). Any ebullition flux event that fell completely within the chamber closure period was processed using a piecewise linear fitting routine (Figure 1c). This routine provided a linear slope of increase before and after the concentration jump, allowing us to quantify the magnitude of the ebullition event. This was converted to $\mathrm{CH}_{4}$ mass released $(\mathrm{mg} \mathrm{CH})$ using chamber volume, temperature and pressure. Methane released could not be determined for ebullition events not completely contained within a chamber closure (Figure 1e), though occurrence, timing and other variables were recorded. Continuous observations of precipitation, temperature, wind speed, water table, relative humidity, and barometric pressure were made at the site, and saved as hourly averages or totals.

\section{Results}

[7] A total of 2,727 ebullition events were identified during 17,352 autochamber flux closures between 27 April and 19 Dec 2009. There were $0-1,370$ bubbles $\mathrm{m}^{-2} \mathrm{~d}^{-1}$ observed during each measurement day, with peak activity occurring in mid-August, which corresponded with peak peat temperature and generally decreasing water table depth (Figure 2). Seasonal mean ebullition frequencies, when scaled by chamber area and closure time, were $403.5 \pm$ 244.5 events $\mathrm{m}^{-2} \mathrm{~d}^{-1}$ (mean \pm standard deviation) for spring (27 April-21 June), $843.5 \pm 384.2$ events $\mathrm{m}^{-2} \mathrm{~d}^{-1}$ during the summer (22 June-21 Sept.), and $272.1 \pm 220.3$ events $\mathrm{m}^{-2}$ $\mathrm{d}^{-1}$ during the fall (22 Sept. -19 Dec.). Seasonal mean peat
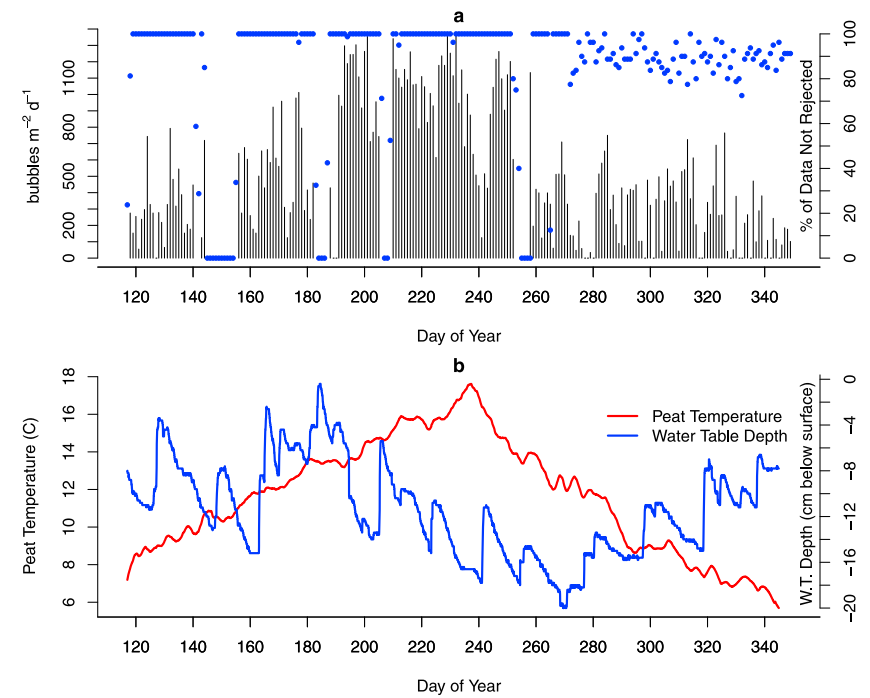

Figure 2. (a) Daily rate of ebullition observed by all the chambers during April 27-December 19, 2009 (black bars), and percentage of chamber closures accepted (blue dots). (b) Daily water table depth relative to peat surface (red line) and average peat temperature at $25 \mathrm{~cm}$ depth (blue line). 

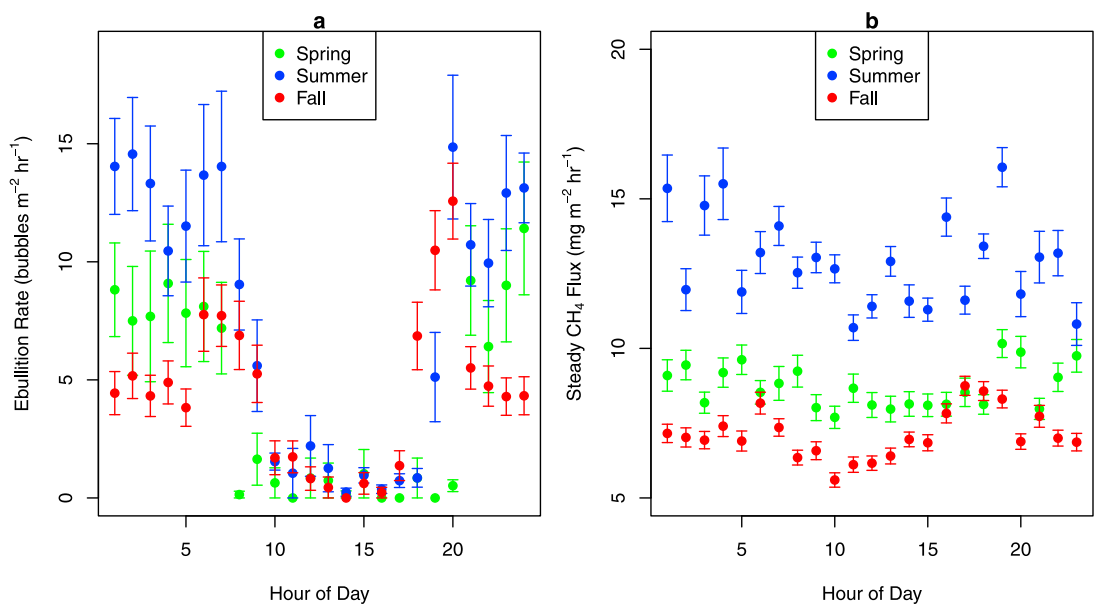

Figure 3. (a) Hourly average ebullition rates from all chambers in 2009 for spring (27 April-21 June; green), summer (22 June-21 Sept.; blue), and fall (22 Sept.-19 Dec.; red). (b) Hourly average $\mathrm{CH}_{4}$ flux for each season based only on steady flux data (e.g., Figure 1a). Error bars represent 1 standard error of the hourly mean.

temperature at $25 \mathrm{~cm}$ below the surface was $10.3 \pm 1.2{ }^{\circ} \mathrm{C}$, $14.6 \pm 1.4{ }^{\circ} \mathrm{C}$ and $8.8 \pm 2.1^{\circ} \mathrm{C}$ (mean \pm standard deviation) for spring, summer and fall respectively. Maximum water table depth reached $20 \mathrm{~cm}$ during the week of 28 Sept. (Figure 2b).

[8] On diel timescales, the rate of ebullition had a distinct pattern in spring, summer and fall (Figure 3a). Peak bubble release occurred between 20:00 and 06:00 for all seasons, with $11.4 \pm 2.8,14.9 \pm 3.0$ and $12.6 \pm 1.6$ bubbles $\mathrm{m}^{-2} \mathrm{hr}^{-1}$ during spring, summer and fall respectively, while daytime rates dropped as low as $0.24 \pm 0.17$ bubbles $\mathrm{m}^{-2} \mathrm{hr}^{-1}$ in summer and 0.0 bubbles $\mathrm{m}^{-2} \mathrm{hr}^{-1}$ in spring and fall. There was not a distinct diel pattern in the 14,582 measurements of steady $\mathrm{CH}_{4}$ flux (Figure $3 b$ ).

[9] Using the piecewise linear fitting routine (Figure 1c), the mass of $\mathrm{CH}_{4}$ released could be quantified for 364 of the 2,727 ebullition events. The mean ebullition event magnitude was $0.18 \mathrm{mg} \mathrm{CH}$ (range: $0.02-1.3 \mathrm{mg} \mathrm{CH}_{4}$, median: $0.15 \mathrm{mg} \mathrm{CH}_{4}$ ) with a right-skewed, log-normal distribution (Shapiro-Wilk: $W=0.9967, \mathrm{p}=0.6854$, Figure 1d). Magnitude seasonality could not be determined due to the uneven seasonal distribution of quantified events; 335 out of the 364 quantified events took place in June, July and August. However, the mean ebullition magnitude for these summer months of $0.19 \mathrm{mg} \mathrm{CH}$ is significantly greater than the combined mean for spring and fall of $0.12 \mathrm{mg} \mathrm{CH}_{4}(\mathrm{t}=3.83$, $\mathrm{p}<0.001)$.

[10] The error associated with the magnitude calculation includes uncertainty in the mean temperature used in the conversion of headspace concentration change to mass of $\mathrm{CH}_{4}$ in $\mathrm{mg}$, as well as the three slope estimates used to isolate the initial and final concentrations with respect to the ebullition spike (Figure 1c). Due to the accuracy of the $\mathrm{CH}_{4}$ measurement itself (total uncertainty of less than $1 \%$ of the reading - LGR Inc.), the resulting error is dominated by the standard deviation in temperature $(<2.5 \%)$. For all ebullition magnitude calculations, the combined error in slope estimates never exceeded $1 \%$. The lower limit for the detection of an ebullition event is determined here by the threshold in the slope increase in the chamber headspace $\mathrm{CH}_{4}$ time series during a given closure that was used to identify potential ebullition events. The smallest event identified with our processing protocol was $0.02 \mathrm{mg} \mathrm{CH}$.

\section{Discussion}

[11] We have shown that automated chambers combined with an ICOS instrument are able to sample both the rate and magnitude of peatland $\mathrm{CH}_{4}$ ebullition at high temporal frequency. Eight months of continual measurements at Sallie's Fen showed distinct seasonal and diel patterns in ebullition frequency. Higher ebullition rates in the summer are likely related to both higher rates of $\mathrm{CH}_{4}$ production and the reduced solubility of $\mathrm{CH}_{4}$ at higher temperatures.

[12] The shape of the magnitude distribution of 364 ebullition fluxes (Figure 1d) was similar to that generated by a reduced-complexity model for $\mathrm{CH}_{4}$ ebullition in porous structured peat [Coulthard et al., 2009]. The model simulated the accumulation of bubbles under non-permeable shelves within the bulk peat, with episodic release of bubbles akin to 'landslides' from 'upside-down sandpiles' that build up depending on the simulated pore structure (i.e., number and width of shelves). These model results indicate that the measured bubble release at Sallie's Fen may be relatively constant and more dependent on $\mathrm{CH}_{4}$ production rates than are ebullition rates at a site with tightly-packed, well-decomposed peat material or confining layers, where episodes may be less frequent but larger in size [Glaser et al., 2004; Rosenberry et al., 2003].

[13] Diel patterns in peatland $\mathrm{CH}_{4}$ flux have been previously observed. Dissolved $\mathrm{CH}_{4}$ concentrations can lag $\mathrm{CO}_{2}$ uptake by wetland plants, indicating an enhancement in $\mathrm{CH}_{4}$ production at night or a decrease in $\mathrm{CH}_{4}$ oxidation [Waddington et al., 1996]. Methanogenesis may also lag behind rhizospheric substrate exudation potentially by hours depending on the plant species [Whiting and Chanton, 1992]. ${ }^{14} \mathrm{C}$-acetate injected into peat monoliths in northeast Greenland was observed in $\mathrm{CH}_{4}$ flux after just 4 hours [Ström et al., 2003]. Nighttime peaks in $\mathrm{CH}_{4}$ flux at hummock sites in a Swedish peatland were related to lower surface oxidation 
rates at night [Mikkela et al., 1995]. Our data support the hypothesis that any lags occurring during carbon uptake, exudation and subsequent utilization that result in enhanced $\mathrm{CH}_{4}$ flux and ebullition, are on the order of hours. However, the steady flux data, including plant-mediated diffusion (e.g., Figure 1a), does not exhibit clear diel variability (Figure $3 \mathrm{~b}$ ). This is not consistent with primary production and subsequent root exudation playing a role in the observed diel ebullition pattern, unless the $\mathrm{CH}_{4}$ production generating the bubbles is deep in the peat, and the diel signal in the diffusive flux is damped by the time it reaches the surface (diffusive flux away from a sinusoidal source results in damped and lagged oscillations, with a damping distance related to the diffusivity of the medium and the frequency of oscillations). This needs to be further investigated with concurrent NEE measurements and, ideally, isotope analysis of peat, pore water, and gas fluxes in order to trace source signatures [Santoni et al., 2010].

[14] Other variables with distinct daily patterns were correlated with ebullition timing; horizontal wind speed, relative humidity and air temperature accounted for $63 \%, 76 \%$ and $54 \%$ of ebullition variation, respectively, when hourly averages were analyzed with non-linear regression. Multicollinearity within these factors limits the utility of multiple regression analysis for determining the most likely driver, though the possibility that any of these factors affect ebullition has not been ruled out. In particular, wind speed, a proxy for turbulence, may affect surface layer peat methanotrophy by rapidly re-oxygenating surface peat pore spaces. Variations in turbulence have been shown to affect rates of upland soil gas exchange on diel timescales [Kimball and Lemon, 1971].

[15] It is important to note that ebullition may also occur as a steady stream of relatively small bubbles, which would result in a linear increase of chamber headspace $\mathrm{CH}_{4}$ concentration over time [Coulthard et al., 2009]. Thus, the data presented here represent episodic ebullition, which may be less than total ebullition.

\section{Conclusions}

[16] $\mathrm{CH}_{4}$ ebullition rates at Sallie's Fen vary on diel and seasonal timescales. Our results indicate that the nighttime enhancement in ebullition may be important to the overall $\mathrm{CH}_{4}$ budget, especially given that the bulk of $\mathrm{CH}_{4}$ fluxes reported in the literature over the past 30 years were made with manual chambers during the daytime. Further examination with long-term continuous datasets from varying sites is warranted. Work is currently underway to estimate the total contribution of ebullition at Sallie's Fen using the full time series of $\mathrm{CH}_{4}$ flux and incorporating field data into a process-based model. We have shown that ebullition events are not necessarily rare releases of $\mathrm{CH}_{4}$ from depth, triggered by overburden pressure events or subsurface buildup beneath confining layers; rather ebullition represents a regular flux pathway for $\mathrm{CH}_{4}$ as typical as diffusion and plant transport.

[17] Acknowledgments. This research was supported in part by the U.S. Department of Energy's Office of Science (BER) through the Northeastern Regional Center of the National Institute for Climate Change Research and the Research and Discover program by the University of
New Hampshire and NASA GSFC. Special thanks to Eduardo Miranda and Michael Keller for their contributions to the success of this project.

[18] The Editor thanks two anonymous reviewers for their assistance in evaluating this paper.

\section{References}

Arneth, A., et al. (2010), Terrestrial biogeochemical feedbacks in the climate system, Nat. Geosci., 3(8), 525-532, doi:10.1038/ngeo905.

Bartlett, K., and R. C. Harriss (1993), Review and assessment of methane emissions from wetlands, Chemosphere, 26, 261-320, doi:10.1016/ 0045-6535(93)90427-7

Bartlett, K. B., P. M. Crill, J. A. Bonassi, J. E. Richey, and R. C. Harriss (1990), Methane flux from the Amazon River floodplain: Emission during rising water, J. Geophys. Res., 95(D10), 16,773-16,788, doi:10.1029/ JD095iD10p16773.

Bubier, J., P. Crill, and A. Mosedale (2002), Net ecosystem exchange measured by autochambers during the snow-covered season at a temperate peatland, Hydrol. Processes, 16, 3667-3682, doi:10.1002/hyp.1233.

Bubier, J., P. Crill, A. Mosedale, S. Frolking, and E. Linder (2003), Peatland responses to varying interannual moisture conditions as measured by automatic $\mathrm{CO}_{2}$ chambers, Global Biogeochem. Cycles, 17(2), 1066, doi:10.1029/2002GB001946.

Bubier, J., T. Moore, K. Savage, and P. Crill (2005), A comparison of methane flux in a boreal landscape between a dry and a wet year, Global Biogeochem. Cycles, 19, GB1023, doi:10.1029/2004GB002351.

Burrows, E. H., J. L. Bubier, A. Mosedale, G. W. Cobb, and P. M. Crill (2005), Net ecosystem exchange of carbon dioxide in a temperate poor fen: a comparison of automated and manual chamber techniques, Biogeochemistry, 71(1), 21-45, doi:10.1007/s10533-004-6334-6.

Comas, X., and L. Slater (2007), Evolution of biogenic gases in peat blocks inferred from noninvasive dielectric permittivity measurements, Water Resour. Res., 43, W05424, doi:10.1029/2006WR005562.

Coulthard, T. J., A. J. Baird, J. Ramirez, and J. M. Waddington (2009), Modeling methane dynamics in peat: Importance of shallow peats and a novel reduced-complexity approach for modeling ebullition, in Carbon Cycling in Northern Peatlands, Geophys. Monogr. Ser., vol. 184, edited by A. J. Baird et al., pp. 173-185, AGU, Washington, D. C.

Crill, P. M., K. B. Bartlett, R. C. Harriss, E. Gorham, E. S. Verry, D. I. Sebacher, L. Madsar, and W. Sanner (1988), Methane flux from Minnesota peatlands, Global Biogeochem. Cycles, 2(4), 371-384, doi:10.1029/ GB002i004p00371.

Glaser, P. H., J. P. Chanton, P. Morin, D. O. Rosenberry, D. I. Siegel, O. Ruud, L. I. Chasar, and A. S. Reeve (2004), Surface deformations as indicators of deep ebullition fluxes in a large northern peatland, Global Biogeochem. Cycles, 18, GB1003, doi:10.1029/2003GB002069.

Houweling, S., F. Dentener, and J. Lelieveld (2000), Simulation of preindustrial atmospheric methane to constrain the global source strength of natural wetlands, J. Geophys. Res., 105(D13), 17,243-17,255, doi:10.1029/ 2000JD900193.

Kimball, B. A., and E. R. Lemon (1971), Air turbulence effects upon soil gas exchange, Soil Sci. Soc. Am. Proc., 35, 16-21, doi:10.2136/sssaj1971. 03615995003500010013x.

King, J. Y., W. S. Reeburgh, and S. K. Regli (1998), Methane emission and transport by arctic sedges in Alaska: Results of a vegetation removal experiment, J. Geophys. Res., 103(D22), 29,083-29,092, doi:10.1029/ 98JD00052.

Mikkela, C., I. Sundh, B. H. Svensson, and M. Nilsson (1995), Diurnal variation in methane emission in relation to the water table, soil temperature, climate and vegetation cover in a Swedish acid mire, Biogeochemistry, 28,93-114, doi:10.1007/BF02180679.

Rosenberry, D. O., P. H. Glaser, D. I. Siegel, and E. P. Weeks (2003), Use of hydraulic head to estimate volumetric gas content and ebullition flux in northern peatlands, Water Resour. Res., 39(3), 1066, doi:10.1029/ 2002 WR001377.

Santoni, G. W., B. H. Lee, J. P. Goodrich, R. K. Varner, P. M. Crill, J. B. McManus, D. D. Nelson, M. S. Zahniser, and S. C. Wofsy (2010), Eddy covariance and autochamber measurements of methane isotopologues using a novel ${ }^{13} \mathrm{CH}_{4}$ quantum cascade laser spectrometer, Eos Trans. $A G U$, 91(52), Fall Meet. Suppl., Abstract B12B-05.

Segers, R. (1998), Methane production and methane consumption: a review of processes underlying wetland methane fluxes, Biogeochemistry, 41, 23-51, doi:10.1023/A:1005929032764.

Strack, M., E. Kellner, and J. M. Waddington (2005), Dynamics of biogenic gas bubbles in peat and their effects on peatland biogeochemistry, Global Biogeochem. Cycles, 19, GB1003, doi:10.1029/2004GB002330.

Ström, L., A. Ekberg, M. Mastepanov, and T. R. Christensen (2003), The effect of vascular plants on carbon turnover and methane emissions from a tundra wetland, Global Change Biol., 9, 1185-1192, doi:10.1046/ j.1365-2486.2003.00655.x. 
Tokida, T., T. Miyazaki, M. Mizoguchi, O. Nagata, F. Takakai, A. Kagemoto, and R. Hatano (2007), Falling atmospheric pressure as a trigger for methane ebullition from peatland, Global Biogeochem. Cycles, 21, GB2003, doi:10.1029/2006GB002790.

Waddington, J. M., N. T. Roulet, and R. V. Swanson (1996), Water table control of $\mathrm{CH}_{4}$ emission enhancement by vascular plants in boreal peatlands, J. Geophys. Res., 101(D17), 22,775-22,785, doi:10.1029/ 96JD02014.

Whalen, S. C. (2005), Biogeochemistry of methane exchange between natural wetlands and the atmosphere, Environ. Eng. Sci., 22, 73-94, doi:10.1089/ees.2005.22.73.

Whiting, G. J., and J. P. Chanton (1992), Plant dependent methane emissions in a subarctic Canadian fen, Global Biogeochem. Cycles, 6(3), 225-231, doi:10.1029/92GB00710.
Wuebbles, D. J., and K. Hayhoe (2002), Atmospheric methane and global change, Earth Sci. Rev., 57, 177-210, doi:10.1016/S0012-8252(01) 00062-9.

P. M. Crill, Department of Geological Sciences, Stockholm University, SE-106 91 Stockholm, Sweden.

B. N. Duncan, NASA Goddard Space Flight Center, Code 613.3, Greenbelt, MD 20771, USA.

S. Frolking, J. P. Goodrich, and R. K. Varner, Complex Systems Research Center, University of New Hampshire, 8 College Rd., Durham, NH 03824, USA. (jpd2@unh.edu) 